\title{
Faith Development, Religious Styles and Biographical Narratives: Methodological Perspectives
}

\author{
Barbara Keller \& Heinz Streib \\ Universität Bielefeld, Germany \\ Barbara.Keller@uni-bielefeld.de; Heinz.Streib@uni-bielefeld.de
}

\begin{abstract}
Narrative study of religious lives has formed part of numerous projects at the Bielefeld Research Center for Biographical Studies in Contemporary Religion. An essential instrument in our designs, which mostly combine qualitative and quantitative methods, is the Faith Development Interview (FDI). In response to longstanding criticism its cognitive structural framework has been revised in respect of styles and schemata. The religious styles perspective examines the self as articulated in narratives and associates it with affectivity and emotion. This article gives an overview of our theoretical and methodological revisions, which take cognizance of current developments in lifespan developmental and clinical psychology such as attachment, mentalization and wisdom. We illustrate the implementation of these advances with a case study from our current study of 'spirituality', ${ }^{1}$ which we locate in the complex multi-method design, and outline the triangulation of qualitative and quantitative data.
\end{abstract}

Keywords

biography, faith development, religious styles, narrative, triangulation

\section{Exploring Religious Lives at the Bielefeld Research Center for Biographical Studies in Contemporary Religion}

At the Bielefeld Research Center for Biographical Studies in Contemporary Religion biographical approaches and narrative methods have been used in a series of research projects, for example the study of fundamentalist Christian biographies (Streib 1999, 200o); the study of deconversion in Germany and the USA, which explored deconversion from fundamentalist and new religious groups and, in a second phase, from established churches and main line denominations (Streib et al. 2009); and the current study of the semantics of spirituality, in which, again comparing Germany and the USA, a more general exploration of the development of people's religiosity, spirituality or worldview

\footnotetext{
1 We refer here to respondents' use of the word, not to the scientific concept.
} 
in biographical context is crucial. In this research context the Faith Development Interview (FDI, Fowler 1981, Fowler, Streib \& Keller 2004) is used to study religious biographies.

The FDI, a semi-structured interview, is a method devised to explore people's 'faith', which Fowler defines comprehensively as follows:

In the most formal and comprehensive terms I can state it, faith is: People's evolved and evolving ways of experiencing self, others and world (as they construct them) as related to and affected by the ultimate conditions of existence (as they construct them) and shaping their lives' purpose and meanings, trusts and loyalties, in the light of the character of being, value and power determining the ultimate conditions of existence (as grasped in their operative images - conscious and unconscious — of them) (Fowler 1981, p. 92f).

According to Fowler (1996, p. 168f.) the concept of faith "aims to include descriptions of religious faith as well as the less explicit faith orientations of individuals and groups who can be described as secular or eclectic in their belief and values orientations". This broad concept of faith includes implicit and experience oriented "patch work" versions of religion deemed "spiritual" as well as secular orientations. It appears far-sighted with respect to presentday spiritual questing that can occur outside specific religious traditions (Hood 2003; Zinnbauer \& Pargament 2005; Streib \& Hood, 2011).

Fowler's conception of faith has seven aspects: logic (Piaget), perspective taking (Selman), moral judgment (Kohlberg), bounds of social awareness, locus of authority, forms of world coherence, and symbolic functioning. These seven aspects are assumed to develop as structural wholes in six stages in an invariant, irreversible sequence. The stages of faith are assumed to be loosely related to age: (1) intuitive-projective faith (<6 years); (2) mythic-literal faith (7-12 years) oriented to reward and punishment; (3) synthetic-conventional faith (adolescence, adulthood) oriented to one's own group and implicit reasoning; (4) individuating reflective faith with explicit systemic reasoning; (5) 'conjunctive' faith, characterized by 'second naiveté', which recognizes the evocative power inherent in symbols; and, finally, and rarely identified in empirical reality, (6) universalizing faith, described as loyalty to being and purged of ego striving (adulthood and late adulthood).

To identify the aspects of faith the FDI proceeds in four major steps and invites respondents to reflect on their lives (life review), their relationships, their values and commitments, and their religiosity. Interviewees respond by presenting, explaining or justifying their lives and opinions. A special feature of the FDI format - motivated by the autobiographical questions at the beginning - is that interviewees respond by reporting events and by telling stories and autobiographic narratives. 
The traditional evaluation condenses such rich material (including the diverse narrative data) elicited by the FDI by calculating one score which is assumed to identify the faith stage. We regard this as a reductive research method. Hence in what follows we discuss revisions and demonstrate translations of conceptual advances towards empirical methods.

\section{From Stages of Faith to Religious Styles}

Streib's critical appreciation of Fowler's work led him to define areas for further work, resulting in the research programme of the religious styles perspective (e.g. Streib 1991, 2001, 2003a, 2003b, 2005). In a recent paper (Streib 2010, p. 1) he reconstructs Fowler's project as an "ambitious search for a combined structural-developmental and liberal-theological plausibility" which, he judges, is "not without tension". For example, the sixth and final stage of universalizing faith has rarely been identified in research and is based on a teleological and eschatological theological proposition. In fact, in empirical studies most adults could be located in stage 3 (synthetic-conventional) or stage 4 (individuatingreflective) (see e.g. the data in Fowler 1981; Streib et al. 20o9; Aygün 2010). Hence in Streib's conception of religious styles stage 6 has been discarded.

Streib (2001; 2010; forthcoming) also challenges the assumptions of the structural wholeness, irreversibility and sequentiality of the stages. The model of religious styles dispenses with these a priori assumptions. As a result biographical trajectories toward less refined or reflective forms of religion, such as fundamentalist turns in adulthood, can be explained more satisfactorily, namely as revivals of earlier stages. Focusing on the implications of the religious styles perspective for the research method in FDI evaluation, Streib (2005) suggests paying more attention to the individual aspects of faith, which allows for divergent stage assignment of aspects and thus for aspect-specific profiles (rather than losing information by averaging assigned scores across aspects). Consequently our careful revision of the original evaluation procedure in the third edition of the Manual for faith development research started by rearranging stage assignment according to aspects of faith (Fowler, Streib \& Keller 2004). This procedure was used in the deconversion studies (Streib et al. 2009; see p. 117 for an example). In our current research project on spirituality this is pursued further by explicitly documenting the stage assignment of each single rating in a profile of aspects.

This procedure makes it obvious when a person displays different levels of faith development in different aspects of faith. 'Progress' in one aspect may be accompanied by 'regression' in another. In line with Streib's assumption of the presence of more than one style in a single FDI, divergent (heterodyning) 
configurations of stages/styles can be identified and, in numerical form, transferred to data bases for further calculation, or represented graphically as a linear figure to illustrate case studies. Here we show the profile of Karin B. ${ }^{2}$ from the current spirituality study.

We would assign Karin a stage score of 3 if we calculate the average across all aspects; but then we would lose the information that there are aspects on which Karin scores higher and aspects on which she scores lower. The revision with aspect-specific evaluation acknowledges the multidimensionality of (faith) development.

Integrating insights from current discourse in developmental psychology, the religious styles perspective also looks at the contextuality of faith development across the person's lifespan. This allows for different configurations of cognitive, affective and emotional development, and can be linked with integrative models in current psychology: models of development which adopt a lifespan perspective. Rather than seeing development as a sequence of predefined stages, it is conceptualized functionally and contextually as selective agerelated change in adaptive capacity (Baltes, Lindenberger \& Staudinger 2006, p. 580). In this perspective successful development refers to functional balance and to "the capacity to move between levels of knowledge and skills, rather than to operate at one specific developmental level of functioning" (Baltes, Lindenberger \& Staudinger 1998, p. 1046).

Streib' s model (and visualization) of religious styles allows for the reappearance of earlier, less refined forms of faith or the co-existence of (elements of) different styles (heterodyning). It is hierarchical (from early to later life, from basic to advanced, from simple to complex), but there is no exclusive, onedirectional linear trajectory (Streib 2001, p. 150).

Streib's earlier criticism focused on neglect of the self with its affects and biographical contexts in religious development. He advocated a reversal of the model of developmental forces, with reference to Noam's (1990, p. 378) criticism: "It is my view that cognitively based theorists have overlooked the central structuring activities of the self by defining the epistemic self as the sole representative of structure. In the process, I believe, the cart was placed before the horse, life history became content to the structure of the epistemic self ... Epistemology replaced life history." Noting that much of the biographical information is not evaluated in the FDI, Streib suggests using narrative and reflective responses in the interview in addition to the life history that the interviewee offers (Streib 2005, pp. 108-111), hence an "integration of narrative analysis with developmental analysis" (Streib 2005, p. 113).

\footnotetext{
2 This is a pseudonym.
} 
Figure 1: Profile of Stage Assignments Across Aspects

Faith Stages

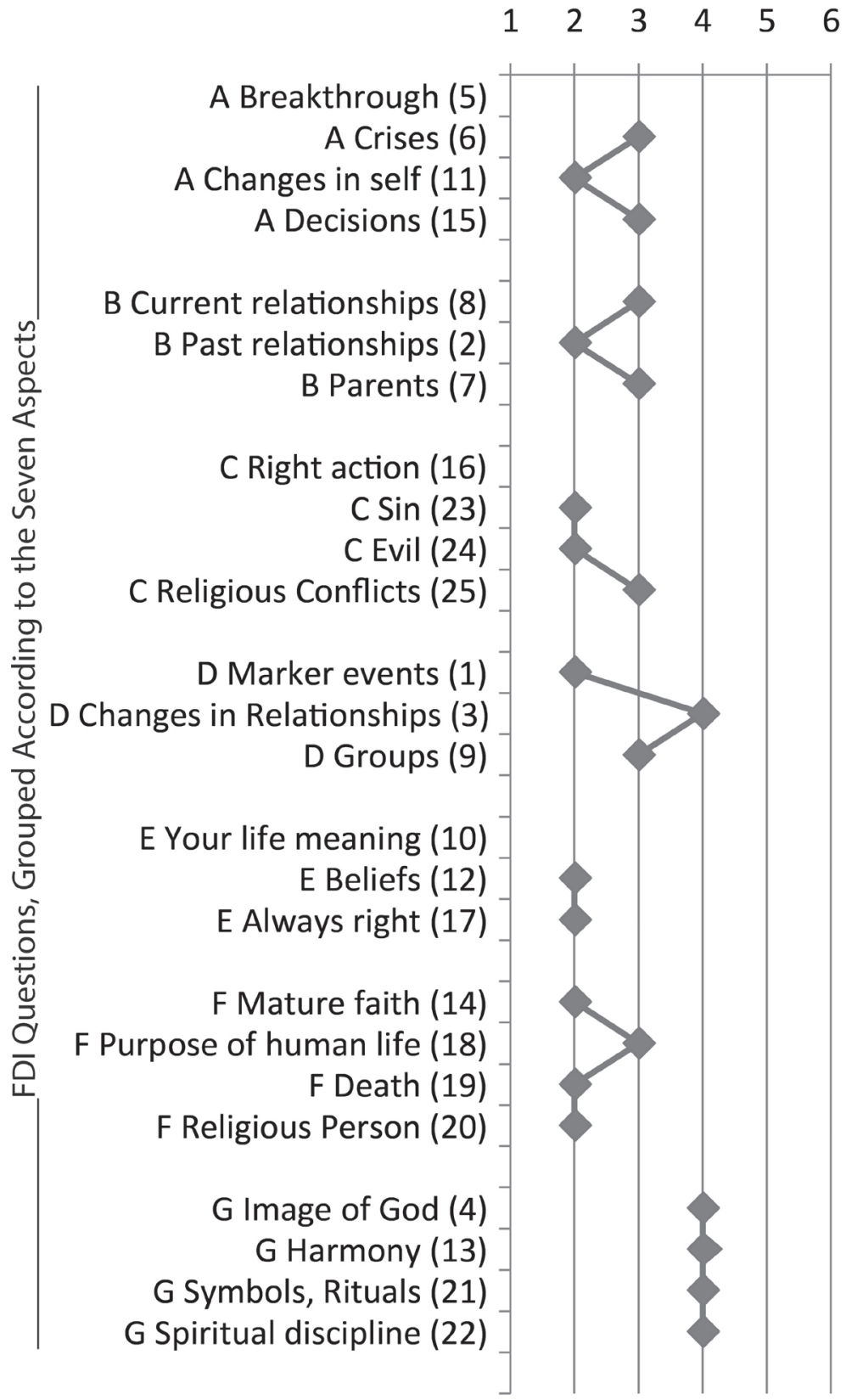


More attention to the affective and relational self and to biography implies inclusion of new concepts and new dimensions - in both scoring procedure and narrative analysis. This is based on the narrative turn in psychology and recent developments in clinical and developmental research.

\section{Attending to Narrative, Relationship, Life World: New Variables}

Autobiographic narrative is linked to self and self-regulation: the ability to create coherence and continuity in one's life story contributes to a mature, healthy psycho-social identity. This is supported by Pennebaker's research on the positive effect of narrative processing of negative experience - an approach that can be seen as a successful transformation of the 'talking cure' into a 'writing cure': repeatedly writing about a traumatic event with increasing causal connections and words indicating insight is conducive to improved mental and physical health (Pennebaker \& Chung, forthcoming). Narrative coherence and complexity can thus be interpreted as indicators of integration of life experience and markers of adult development.

Our recent modification of FDI evaluation includes an estimate of narrative coherence. The estimate is based on the first question of the life review section, where respondents are asked to think of their life as if it were a book and are invited to describe its chapters. This specific rating concerns the complexity and integration of life chapters as actually narrated by the respondent in the interview. Are there life chapters? If so, how are they presented? Our new scoring sheet (Streib 2012) includes a rating table with several options. Further aspects of narrative are discussed below when we demonstrate how to incorporate different data into a case study.

\subsection{Narrative Coherence}

Karin first presents the chapters of her life in a conventional way and order: "Yes, early, early childhood. Earliest childhood, childhood, adolescence perhaps divided into two sections, (childhood in) a Scandinavian country and move to Germany. Young adult, being a parent, teenager, mother, working, always, and yes, I think so."3 This kind of 'life story abstract' is Karin's response to the first part of the first question. She was asked what 'marker events' stand out as important; she answers by giving a chronology of key events which come

${ }^{3}$ Ja, ganz frühe Kindheit. Früheste Kindheit, Kindheit, Jugend vielleicht auch in zwei Abschnitte unterteilt, Skandinavien/Deutschland. Junger Erwachsener, Elternzeit, Teeny, Mutter, berufstätig immer und ja denke ich so. 
Figure 2: Rating of Narrative Coherence ("1" = "yes")

\begin{tabular}{lc}
\hline Evaluations / Ratings & Score \\
\hline The interviewee divides her/his life in chapters (Yes/No). & 1 \\
Life chapters are there, but unconnected; no details are given & \\
Life chapters are loosely connected (e.g. structure is conventional \\
(merely temporal) referring to years ("in my twenties, thirties..."), \\
no narrative episodes are mentioned chronology, labels, no explicit \\
narrative \\
There is a clear life chapter structure with narrative episodes \\
connected to each other, but there is no reflection or emotional \\
evaluation on events. \\
Life chapters are tied together, narrative structure is complex and \\
reflected, accompanied by emotional evaluation
\end{tabular}

to mind. This chronology starts with changes in her family when she was a baby - and this may explain why she stresses early childhood in the abstract at the beginning of the interview. Then Karin proceeds to the illness her parents had to cope with, to leaving home, marriage, having children, children leaving home. Her response was rated as "conventionally structured and without emotional evaluation" (see Figure 2).

\subsection{Attachment}

Attachment theory proposes "the propensity of human beings to make strong affectional bonds to particular others" (Bowlby 1977, p. 201). Based on observational studies of young children and their mothers, Bowlby assumes an attachment system that evolved to keep infants close to their caretakers under conditions of danger or threat. Attachment theory posits that a haven of safety or a secure base serves as a point of departure and a place of safe return for preschool children when exploring their environment. The Adult Attachment Interview (AAI; George, Kaplan \& Main 1987) was developed for the exploration of adult attachment. Evaluations of these interviews are based on adults' narratives and reflections on their childhood and early relationships. These evaluations, which centre on integration of experience, predict the quality of parents' interaction with their children and the security of the children's attachment. Secure attachment results from sensitive interaction with caretakers, while insecure attachment styles (dismissive or preoccupied) relate to either distant or ambivalent relationships. A fourth classification is a fearful attachment style, associated with unpredictable or even abusive parenting. 
Figure 3: Rating of Attachment Dimensions (rating "1" = "very low/absent" through "5" = "very high")

\begin{tabular}{lc}
\hline Evaluations / Ratings & Score \\
\hline $\begin{array}{l}\text { Secure: open discussion of relationship and attachment, realistic } \\
\text { forgiving perspective, vivid description }\end{array}$ & 4 \\
$\begin{array}{l}\text { Insecure avoidant / dismissive: stressing independence, emotional } \\
\text { distance, downplaying rejections }\end{array}$ & 1 \\
$\begin{array}{l}\text { Insecure anxious / preoccupied: great efforts, to gain attention and } \\
\text { support, indications of low self-esteem }\end{array}$ & 1 \\
\begin{tabular}{l} 
Fearful (disorganized): negative attitude toward self and others \\
\hline
\end{tabular} & 1 \\
\hline
\end{tabular}

Secure attachment is hypothetically linked with correspondence (same God/ religion as parents), while compensation (God as surrogate for insensitive parent/turning to a different religion) is linked with insecure attachment (Kirkpatrick 1992, 2005). Granqvist and Hagekull (1999) add the idea of socialized correspondence, suggesting that in the case of secure attachment religion reflects partial adoption of a sensitive caregiver's religion. Recently Granqvist $(2010,10-11)$ stated that "religion in the case of secure attachment develops from (a) generalized, positive representations of self and other (IWM), and (b) partial adoption of a sensitive caregiver's religion (social aspect). If parents have been observably religious, secure offspring are expected to be as well, in which case their perceptions of God will more or less mirror that of a reliably sensitive attachment figure. Second, with the compensation pathway, religiosity in the case of insecure attachment is held to develop from higher-order distress regulation strategies, characterized by the use of God as a surrogate attachment figure."

In the FDI the questions about parents are evaluated for attachment, based on how interviewees portray their relationship with their parents. For an operationalization we draw on Bartholomew and Horowitz (1991) and their suggestion to conceive of the four attachment styles as four dimensions, which we evaluate by means of 5 -point rating scales.

Karin was seen as basically securely attached. The scores will be entered into the data base with other quantitative data (e.g. from questionnaires), while the analysis of her faith development will be based on the characterization.

\subsection{Mentalization, Reflective Function and Self-Regulation}

Attachment theory stresses the affective conditions for exploration and cognitive development and thinking. Alluding to Winnicott's (1971) paper "Playing 
and reality", Fonagy and Target present mentalization operationalized as reflective functioning. Winnicott $(1971,15)$ saw the intermediate area as offering relief from the ongoing task of reality acceptance and as the origin of arts and religion. According to Fonagy and Target mentalization develops as the child, protected by secure attachment, learns to move back and forth between pretend play and reality, and realizes that there is an inner life and that experience is mediated by inner processes. In its broadest sense mentalization refers to awareness and understanding of one's own and others' inner worlds; it is a relational and integrative concept describing the lifelong task of making sense of experience. Recently Fonagy and Target (2007) have explained how mentalization, emerging in early intersubjectivity, shapes the understanding of external reality. For the development of infants' self it is crucial to find their image in the mind of their caretaker and to be treated as persons with an inner life and a perspective on the outer world. From the perspective of the child, who does not yet realize that there are minds mediating every kind of knowledge, there is just 'reality'. Fonagy and Target (2007, p. 922) note: "Piaget's concept of egocentrism has exactly the opposite emotional valence to what is actually taking place. It is not the overvaluing of private knowledge but the undifferentiated experience of shared knowledge that hinders perspectivetaking.... (Y)oung children do not yet know fully that their internal world is private and individual." This change of perspective suggests that the development of self-related mental operations and their monitoring depend on a secure attachment context.

To return to faith development supplied with this knowledge, we may conclude that the notions of mentalization, reflective function and self-regulation imply a reversal of the Piaget-inspired perspective on cognitively structured faith development proposed by Fowler. By contrast, the mentalization-based attention to relationship corresponds with Streib's and Noam's claim that the affective and emotional self precedes and structures the epistemic self. This has implications for modelling faith development: while the Piaget/Kohlberginspired model recognizes religious cognition, the mentalization informed perspective refers to a safe relationship, a secure environment in which to explore the other person's inner life, including her religiosity.

Applied to faith development, the mentalization perspective leads one to expect that, in the case of 'good enough' caretakers (Winnicott, 1971), children participate in the religious lives of their caretakers, taking this shared reality as reality per se, because they are as yet unaware of the possibility of different minds and perspectives. These different modes of handling inner experience and outer world are supposed to occur in a developmental sequence: 
Figure 4: Rating of Mentalization (rating "1" = "very low/absent" through " 5 " = "very high"

\begin{tabular}{lc}
\hline Evaluations / Ratings & Score \\
\hline Awareness of the nature of mental states & 2 \\
The explicit effort to tease out mental states underlying behavior & 1 \\
Recognizing developmental aspects of mental states & 3 \\
Mental states in relation to the interviewer & 1 \\
\hline
\end{tabular}

- the teleological stance (cause-effect, little awareness of inner experience),

- psychic equivalence (what is in the mind corresponds with reality),

- pretend mode (what is in the mind exists only in the mind, as in fantasy play), and finally

- mentalization (integration of psychic equivalence and pretend mode: mind matters in the understanding of reality, also when it comes to understanding religions and worldviews).

In line with the foregoing developmental conceptions the different modes can be imagined as appearing in a sequence, then overlapping, interacting and remaining available throughout the lifespan and leading to different manifestations in different domains of life, also in different forms of faith. Structurally this conception resembles Streib's model of religious styles: the teleological mode, psychic equivalence and pretend mode precede mentalization. They remain available and are activated when mentalization is not functional or breaks down, for example under severe stress. ${ }^{4}$

We use these modes in FDI evaluation and developing case studies. For other types of analysis, such as exploring the relationship of mentalization with other variables, mentalization is operationalized as reflective functioning in a continuous variable. The measure of mentalization which is used in most studies is the reflective functioning scale. It was developed as an AAI subscale (Fonagy et al. 1998). Originally it was "examined as a potential mediator through which parents, by anticipating and understanding their children's emotional reactions, might promote secure attachment" (Rudden et al. 2008, 185). For our new scoring procedure we have adapted a version of the AAI/ mentalization assessment and use it to assess the FDI questions on relationships. We explore different dimensions of reflective functioning such as aware-

4 It may be dysfunctional for an abused child to imagine the inner life of a hostile caretaker. It may be functional, however, to look for cues for what may happen next. 
ness of the nature of mental states, recognizing the developmental character of mentalization, and use a 5-point rating (cf. Meehan et al. 2009). We have included this in our scoring, as shown in Figure 4, in which we again inspect Karin's interview, and find that her mentalization skills are rated as average and lower.

\subsection{Wisdom-Related Behaviour: Reflecting Worldview and Religion in the Life World}

Regarding the relation of religion and life world, the FDI elicits answers to the question of how religious conflicts or conflicts arising from divergent worldviews may be resolved. This allows an assessment of wisdom as expressed in the interview.

For a conceptual and empirical orientation we draw on research on wisdom understood as referring to the fundamental pragmatics of life or wisdomrelated behaviour. Operationally this definition entails five criteria: factual knowledge, procedural knowledge, contextualism, value relativism and uncertainty. Wisdom related behaviour was originally explored by rating thinkingaloud responses to fictional vignettes of conflicts (Staudinger, Smith \& Baltes 1994). Baltes, Lindenberger and Staudinger (2006, 608) state: "People high on wisdom-related knowledge exhibited a more complex and modulated structure of emotions and preferred conflict resolution strategies that are based on dialogue rather than power." We have adapted the procedure of the assessment of wisdom and applied it to faith development interviewees' suggestions on how to resolve religious conflict. Figure 5 shows how we included this in the new score sheet, again using a 5-point scale. Karin shows moderate to average scores.

With the introduction of these new concepts we hope to evaluate dimensions of the relational self, self-regulation and the self in relation to culture in the FDI. From the discussion so far these evaluations clearly focus on quantifiable data (scores) according to predefined dimensions. This should not preclude qualitative evaluation and the compilation of case studies. In the final section of this article we turn to a single case study, again using Karin's data. But first we describe our procedure of interpretive narrative analysis.

\section{Narrative Analysis of Faith Development}

In this part of our work we take up the thread of the narrative turn in personality and developmental psychology. Narrativity was put on the research agenda in psychology by M. and K. Gergen (2010), McAdams (1990, 1993), Josselson and 
Figure 5: Rating of Wisdom-related Behavior (rating " 1 " = "very low/absent" through " 5 " = "very high"

\begin{tabular}{lc}
\hline Evaluations / Ratings & Score \\
\hline $\begin{array}{l}\text { Rich factual knowledge about the fundamental pragmatics of life } \\
\text { Rich procedural knowledge about dealing with the fundamental } \\
\text { pragmatics of life }\end{array}$ & 2 \\
$\begin{array}{l}\text { Life-span contextualism: understanding one's life contexts and } \\
\text { their temporal (developmental) relations }\end{array}$ & 3 \\
$\begin{array}{l}\text { Value-relativism: knowledge about the differences in values and } \\
\text { life goals }\end{array}$ & 2 \\
$\begin{array}{l}\text { Uncertainty: knowledge about the relative uncertainty of life and } \\
\text { its management }\end{array}$ & 2 \\
\hline
\end{tabular}

Lieblich (1997), and others, who began to study narrative structures in theoretical psychological accounts and used narratives as windows on personality and narrative identity. McAdam's recent publications include the exploration of religious attitudes (McAdams et al. 2008). In one of the rare longitudinal studies Josselson (2009) demonstrates how the meanings of past autobiographic memories are reshaped over time, while contents (facts) are preserved and held together by a layered, multiple self. Habermas (2006) studies autobiographic narrative and reasoning, exploring issues of mental health and development by way of linguistic markers of narrative perspectives. Pasupathi's research (Pasupathi \& Mansour 2006; Pasupathi, Mansour \& Brubaker 2007) focuses on the construction of relations between self and experience in narratives and their change across the lifespan. Clinical attachment and mentalization perspectives suggest that a safe, empathic environment supports productive narrative exploration of one's life (Holmes 2010).

We draw on these methods and concepts for our case studies, building on Streib's (2005) suggestion to take into account the events and experiences reported and the dynamics and processes during the interview. Case studies focus on the reconstruction of biography. The first step consists in identifying different sorts of texts: chronological, reflective and narrative passages of the FDI. For the identification of narratives we rely on the definition by Labov and Waletzky (1967). According to their theory a narrative comprises an orientation, followed by a complication, an evaluation, a resolution and, finally, a coda, which connects the narrative to the present. A narrative may give an example, make a point, give reasons for a turn in one's development and may function similarly to an explicit account such as a justification, an excuse 
(Scott \& Lyman 1968) or a plea for understanding. Another type of text is a chronology, which gives an overview of events joined together by a timeline or a theme.

We then turn to content, identify personal themes, and look for cultural models of reasoning. Next we evaluate the interview trajectory: Which events and experiences are presented early in the interview? What is mentioned later? What is developed into a narrative? Which experiences are presented as selfdefining, which are rendered as distant, discarded? How are these experiences linked to religion and worldview? In longitudinal perspective, are there indicators of change over time? Are there genres, popular stories or other cultural models (Holland \& Quinn 1987) to be discerned?

\section{Case Study}

In this concluding section we illustrate our method of compiling a case study. For an example we again use Karin's FDI. We start with information from the online questionnaire, which consists of a set of quantitative measures and demographic information. Sampling for interviewees was based on analysis of questionnaire data, especially the self-identification as being 'more spiritual' as opposed to 'more religious'.

Karin, 54 years old at the time of the interview, identified herself as "more spiritual than religious" on our forced choice item. She also identified herself as a non-theist. According to her response on the relevant scale her environment at age 12 was "more religious than spiritual". This already indicates a biographic change. But let us listen to Karin's narration:

\subsection{Chronology}

"I think the very first important thing, I do not have memories of that. I was only two months old, I had been adopted by an uncle and aunt, though. I was taken away from my biological mother and came to new parents. This was, I think, the first really big episode. The second was when I was perhaps 11, when my father had a life-threatening disease and my mother suffered so much that she could hardly cope from day to day. Then, I think when I was 17, when I left home, from a small place in the north to $\mathrm{X}$. This was also a radical change. A year later to Germany, another radical change. Marriage, a new radical change, and then only ten years later, a child; then, when a second child came, another radical change and the last, or the last radical change was the children leaving home. This happened gradually, there was no dramatic, radical change. It was 
not like a child is born and everything is turned upside down, it was rather a gradual process and it was OK." 5

\subsection{Reflection}

Karin explains why she left her church:

"Yes, I felt more, more and more problems with the church because I could not conform to what was preached. I did not like the way that church behaved like a club, that congregations gave funny looks when new people attended, or they laughed when visitors did not know exactly how to behave during communion.... The church was doing many good things but also did a lot for itself and I did not feel that I wanted to belong and when I was in my mid-forties I decided to leave and then I started to look around to see what else there was. I read an awful lot, much useless stuff, many useful things. Experimented with my own thoughts on spirituality. Thought what I could accept. Was that possible or not? I don't know exactly what I believe, because I keep telling myself it might well be, it does not have to be. It might be nice if it were like that, it might be nice if it were different."6

In the framework of the deconversion study (Streib et al. 2009) we categorized Karin's trajectory as a privatizing exit: she leaves without joining another religious community. Instead she tells how she became a 'spiritual seeker'.

5 „Ich denke das allererste was vielleicht sehr bedeutsam war, daran kann ich mich nicht erinnern. Das war wo ich zwei Monate alt war, da wurde ich adoptiert von Onkel und Tante allerdings. Ich kam dann halt von der leiblichen Mutter weg und hin zu neuen Eltern. Das war glaube ich so der erste wirklich große Abschnitt. Der zweite war vielleicht als ich 11 war, dass mein Vater lebensbedrohlich erkrankte und meine Mutter ja so darunter litt, dass sie den Alltag nicht im Griff hatte. Dann denke ich als ich 17 war, bin ich von zu Hause weggegangen aus einem kleinen Ort in Norden nach X. Das war auch ein Umbruch. Ein Jahr später nach Deutschland, war wieder ein Umbruch. Auch die Heirat ein neuer Umbruch und dann 10 Jahre später erst ein Kind, dann als noch ein zweites Kind kam ein neuer Umbruch und die letzten oder letzte Umbruch war eigentlich der Auszug der Kinder. Der hat sich allmählich vollzogen, so dass man da nicht, es war kein heftiger Umbruch. Es war nicht so als es wurde ein Kind geboren und alles stand auf dem Kopf, sondern es vollzog allmählich und ja war auch ok."

${ }^{6}$ "Ja, ich habe für mich selber immer mehr Probleme mit der Kirche gespürt, weil ich nicht konform gehen konnte, mit dem was gepredigt wird. Ich mochte es auch nicht dass die Kirche sich wie ein Club aufführt, auch die einzelnen Gemeinden komisch geguckt haben, wenn da neue Leute in den Gottesdienst kamen oder gelacht haben, wenn mal im Abendmahl der Besucher nicht so genau wusste, wie man es da macht. .. Auch die Tatsache das Kirche tut zwar viel Gutes, aber sie tut auch viel für sich und ich hatte nicht das Gefühl das ich dazugehören wollte und habe mich dann entschieden aus der Kirche auszutreten mit etwa Mitte 40 und habe dann angefangen mir anzuschauen, was gibt es denn sonst noch. Ich habe unendlich viel gelesen, viel Unsinn, viel was Sinn macht. Für mich selber viele wirklich spannende Gedankenexperimente gemacht zum Thema Spiritualität. Überlegt was kann ich für mich selber akzeptieren. Könnte das sein, könnte das nicht sein. Was ich glaube weiß ich selber nicht so genau, weil ich sage mir immer, gut es könnte sein, muss nicht sein, es könnte sein. Wenn es so wäre, wäre es nett, wenn es anderes ist kann es auch nett sein." 


\subsection{Narrative}

In Karin's first narrative, evaluated according to the model of Labov and Waletzky (1967), we can identify the following steps:

\begin{tabular}{ll}
\hline And in religious education we had discussed miracles & Orientation \\
\hline and I sat at my desk and could look into the adjoining & Complication \\
room and somehow the rays of light and dust crossed & \\
each other in the air and for a moment I saw a beaming & \\
figure, I thought. I was excited, I was convinced, I had \\
experienced a miracle and I firmly believed that I now \\
had seen Jesus and this is what I told the religious \\
education teacher and I got pasted one. I told it the \\
major at the Salvation Army and she threatened to \\
expel me. Then there was this handicraft afternoon \\
meeting at church, it was the pastor's wife who was in \\
charge of this, and she threw me out.
\end{tabular}

And then I was convinced: They do not believe what Evaluation they are telling.

Then I asked myself what is going on here? What are Resolution they doing, if they do not believe this?

I believe this was the first moment where I started to Coda doubt, if what they are wanting to drill into me really has anything to do with reality at all. ${ }^{7}$

The coda connects the narrative with the present. Focusing on the first moment of doubt, this coda states that Karin tells the story of the beginning of the end of her religiosity. It can be understood as a deconversion story with moral

\footnotetext{
7 Und wir hatten im Religionsunterricht in der Schule über Wunder gesprochen

und ich saß am Tisch und konnte in den Nebenraum reinschauen und irgendwie kreuzten sich da Lichtstrahlen und Staub in der Luft und ich sah für einen Moment eine leuchtende Gestalt, glaubte ich. Ich war völlig begeistert, ich war sicher ich hatte jetzt ein Wunder erlebt und glaubte fest ich habe jetzt Jesus gesehen und das habe ich dann auch dem Religionslehrer erzählt und es gab fürchterlich einen übergebraten. Ich habe es der Majorin bei der Heilsarmee erzählt, die drohte mit Ausschluss. Dann gab es halt diesen Bastelnachmittag in der Kirche, das war die Frau des Pfarrers die das verrichtete, die schmiss mich raus.

Und da war ich ganz sicher, die glauben nicht an das was sie da erzählen.

Dann habe ich mich gefragt was passiert denn da, was machen die denn da, wenn die das nicht glauben.

Ich glaube das war so der erste Moment, wo ich wirklich anfing zu zweifeln, ob das was sie mir einbläuen wollen, dann auch wirklich so was mit der Wirklichkeit zu tun hat.
} 
criticism as a basic characteristic (Streib et al., 2009, p. 22). It may, however, also indicate an emerging cultural model of a narrative of spiritual development (Holland \& Quinn 1987), centring on leaving hypocritical authorities and embarking on an independent search for the sacred.

\subsection{Trajectory}

The illness of Karin's parents is not mentioned in the titles of her life chapters, which are coherent and conventionally structured according to life phases. It is only discussed later in the interview. Then we learn that illness struck again later in Karin's life, when her husband was seriously ill with cancer and when she had several miscarriages before she gave birth to her children. In her own reflections she seems to insist on gradual change, when she remarks that things introduced as "radical change" happened "by degrees". Should we attribute this to Karin slowly opening up in the course of the interview? Or is there a specific tendency to avoid sorrowful episodes? We might understand this better if we compare this trajectory with other interviews.

\subsection{Summary}

Karin's interview seems to be oriented towards family and community. There is a focus on positive outcomes. Counterfactual thinking is rejected. We see an emphasis on gradual change and harmonious relationships. The vagueness of ideas, reliance on feelings and intuitions give the impression of implicit reasoning. Implicit reasoning is characteristic of stage three of Fowler's model. However, Karin also shows clear individuating-reflective features (stage 4) when explicating the function of symbols which she uses in her spiritual practice. Instrumental-reciprocal reasoning (stage 2) appears when Karin refers to the comfort derived from (naïve) faith. She appears to be well grounded in her relationships, perhaps with a tendency to focus on what is conducive to harmony. Karin's ratings on mentalization and wisdom are estimated as average or lower. Her narrative tells us about moving away from the church and embarking on her own search, motivated by moral criticism in a prolonged, 'gradual' process from her first childhood doubts to de-converting and making a privatizing exit in midlife. These evaluations and considerations, along with our evaluations of other interviews, can lead to comparative discussion. Such discussion enables us to construct a typology of faith biographies. For a more differentiated definition of the resulting picture we may also look at the individual cases from the perspective of the quantitative data. 


\subsection{Triangulation of Qualitative and Quantitative Data}

To demonstrate triangulation - the scrutiny of a phenomenon from more than one methodological perspective - we now merge the reported qualitative data with quantitative data.

In the questionnaire Karin identified herself as "more spiritual than religious". She chose to characterize her environment at age 12 as "more religious than spiritual". From this we conclude that Karin turned from religion to spirituality. Her spiritual turn is also reflected in her questionnaire scores on the scales for personal growth (measuring interest in personal development) and environmental mastery (measuring interest in control of the environment) on Ryff's Psychological Wellbeing and Growth Scale (Ryff 1989). Karin has high scores (above the median) on personal growth and low scores (below median) on environmental mastery. According to the typology suggested by Helson and Srivastava ${ }^{8}$ (2001) this would qualify her as a 'seeker', a person who places more emphasis on her personal development than on her success at controlling her environment — albeit in her own implicit, intuitive way.

\section{Conclusion and Prospect}

This article aimed to demonstrate that there is more to the FDI than a cognitive-developmental structure. But if we no longer rely on a cognitive structuraldevelopmental framework, we need to define alternative ways to study faith development. The religious styles perspective opens up a vista on new research strategies - especially by taking the interviewees' own narration and the rich information embedded in the FDIs seriously. In response to this potential of the FDI, which goes far beyond a single total stage score and yields deeper and broader evaluative perspectives, we developed new and additional measures based on various contemporary discourses in developmental and clinical psychology. This suggests taking the individual interview as starting point for evaluation - in fact, we focused on just one interview in our presentation. Results on additional dimensions of the FDI can be imported into the quantitative data set for statistical analyses. These results, especially the assessment of narrative coherence and the detailed analysis of narrative structure according to Labov and Waletzky (1967), can be used to compile a case study, as demonstrated above.

8 This typology consists of the four possible combinations of personal growth and environmental mastery: environmental mastery and personal growth high ('Achiever'); environmental mastery low and personal growth high ('Seeker'); environmental mastery high and personal growth low ('Conserver'); environmental mastery low and personal growth low ('Depleted'). 
However, our evaluation may go further. Once we have constructed a typology based on the evaluation of a sufficient number of FDIs and religious biographies, we can enter these typological characteristics — as nominal data — in the quantitative data set. That enables us to triangulate typological and dimensional measures and descriptions, and thus give the phenomena we study such as self-identified 'spirituality' in our current study - greater depth. At this level of analysis triangulation entails comparison of FDI evaluations and scores on narratives on the one hand, with quantitative data such as measures of religious schemata, assessments of personality, wellbeing and the like on the other hand. This also allows systematic exploration of faith development by comparing FDI scores and quantitative assessment of religious styles and schemata with the Religious Schema Scale (RSS; Streib, Hood \& Klein 2010).

We conclude with two remarks on the prospects of future research by means of the FDI. First, it would be extremely interesting — and it is our plan — to study faith development in longitudinal designs. If we interview the same person at two or more points in his or her lifetime we could not only assess whether there has been faith development over time, but we could relate and compare the FDI assessments with the person's own biographical narrative about changes that have occurred.

Last but not least, we want to mention the prospect of the therapeutic effect of the narrative interview and its usefulness in counselling and pastoral care (cf. Keller, Klein \& Streib, 2013). Our respondents appreciate the secure space that the FDI offers for exploring their faith development (cf. Holmes 2010). One of our American respondents, when asked to comment at the end of the interview, said:

Well, I just wish there was more stuff like what you all you are doing. ... and I think something like this, where you can talk to a person like this and all they do is listen and not argue back at you, would be really beneficial for a lot of students who at least could learn, like where they are no matter what religion or beliefs or how they have been raised, but to just talk to somebody, to just explain it to yourself really, because all you are doing could be really beneficial for a lot of people who are uncertain. So when they do walk out of the room or they graduate they know where they are and that can be really helpful. So I am really glad to be a part of this. I am glad you are doing this.

\section{References}

Aygün, A. (2010). Religiöse Sozialisation und Entwicklung beimuslimischen Jugendlichen in Deutschland und in der Türkei. PhD dissertation, Universität Bielefeld, Fakultät für Geschichtswissenschaft, Philosophie und Theologie, Abteilung Theologie. 
Baltes, P. B., Lindenberger, U. \& Staudinger, U. M. (2006). Lifespan theory in developmental psychology. In R. Lerner \& W. Damon (eds), Handbook of child psychology. Vol. I. Theoretical models of human development. Hoboken: Wiley.

- (1998). Life-span-theory in developmental psychology. In R. M. Lerner (ed.), Handbook of child psychology. Vol. 1. Theoretical models of human development (pp. 1029-1143). New York: Wiley.

Bartholomew, K. \& Horowitz, L. M. (1991). Attachment styles among young adults: a test of a fourcategory model. Journal of Personality and Social Psychology 61: 226-244.

Bowlby, J. (1977). The making and breaking of affectional bonds. British Journal of Psychiatry 130: 201-210.

Fonagy, P., Target, M., Steele, H. \& Steele, M. (1998). Reflective-functioning manual. Version 5 for application to Adult Attachment Interviews. Unpublished Manuscript.

Fonagy, P. \& Target, M. (2007). Playing with reality IV. A theory of external reality rooted in intersubjectivity. International Journal of Psychoanalysis 88: 917-937.

Fowler, J. W. (1981). Stages offaith. San Francisco: Harper\&Row.

- (1996). Pluralism and oneness in religious experience: William James, Faith Development Theory, and Clinical Practice. In E. P. Shafranske (ed.), Religion and the clinical practice of psychology (pp. 165-186). Washington, DC: American Psychological Association.

Fowler, J. W., Streib, H. \& Keller, B. (2004). Manual for faith development research. Bielefeld: Atlanta.

George, C., Kaplan, N. \& Main, M. (1987). The adult attachment interview. Unpublished manuscript. University of California, Berkeley.

Gergen, K. J. \& Gergen, M. M. (2010). Scanning the landscape of narrative enquiry. Social and Personality Psychology Compass 4(9): 728-735.

Granqvist, P. (2010). Religion as attachment: the Godin Award lecture. Archive for the Psychology of Religion 32: 5-24.

Granqvist, P. \& Hagekull, B. (1999). Religiousness and perceived childhood attachment: profiling socialized correspondence and emotional compensation. Journal for the Scientific Study of Religion 38: 254-273.

Habermas (2006). Who speaks? Who looks? Who feels? Point of view in autobiographical narratives. International Journal of Psychoanalysis 2: 497-518.

Helson, R. \& Srivastava, S. (2001). Three paths of adult development: conservers, seekers, and achievers. Journal of Personality and Social Psychology 80: 995-1010.

Holland, D. \& Quinn, N. (eds.) (1987). Cultural models in language and thought. Cambridge: Cambridge University Press.

Holmes, J. (2010). Exploring in security. Hove: Routledge.

Hood, R. W. (2003). Spirituality and religion. In A. L. Greil \& D. G. Bromley (eds.), Religion: critical approaches to drawing boundaries between sacred and secular (pp. 241-264). Amsterdam: Elsevier.

Josselson, R. (2009). The present of the past: dialogues with memory over time. Journal of Personality $77(3)$ : 647-668.

Josselson, R. \& Lieblich, A. (1997). The narrative study of lives. London: Sage.

Keller, B., Klein, C. \& Streib, H. (2013). Das Interview zur Glaubensentwicklung: Zur Exploration von Spiritualität im psychotherapeutischen Setting. (The Faith Development Interview: Exploring spirituality in therapeutic settings) Spiritual Care 2: 35-43.

Kirkpatrick, L. A. (1992). An attachment-theory approach to the psychology of religion. International Journal for the Psychology of Religion 2: 3-28.

- (2005). Attachment, evolution, and the psychology of religion. New York: Guilford.

Labov, W. \& Waletzky, J. (1967). Narrative analysis: oral versions of personal experience. In I. Helm (ed.), Essays on the verbal and visual arts. Proceedings of the 1966 Annual Spring 
Meeting of the American Ethnological Society (pp. 12-44). Seattle, WA: University of Washington Press.

McAdams, D. P. (1990). The person. An introduction to personality psychology. San Diego: Harcourt Brace.

- (1993). The stories we live by: personal myths and the making of the self. New York: Guilford.

McAdams, D. P., Albaugh, M., Farber, E., Daniels, J., Logan, R. L. \& Olson, B. (2008). Family metaphors and moral intuitions: how conservatives and liberals narrate their lives. Journal of Personality and Social Psychology 95(4): 978-990.

Meehan, K. B., Levy, K. N., Reynoso, J. S., Hill; L. L. \& Clarkin, J. F. (2009). Measuring reflective function with a multidimensional rating scale: Comparison with scoring reflective function on the AAI.Journal of the American Psychoanalytic Association 57: 208.

Noam, G. G. (1990). Beyond Freud and Piaget: biographical worlds — interpersonal self. In T. E. Wren (ed.), The moral domain (pp. 360-399). Cambridge: MIT Press.

Pasupathi, M. \& Mansour, E. (2006). Adult age differences in autobiographical reasoning in narratives. Developmental Psychology. 42(5): 798-808.

Pasupathi, M., Mansour, E. \& Brubaker, J. R. (2007). Developing a life story: constructing relations between self and experience in autobiographical narratives. In Human Development 50: $85^{-110 .}$

Pennebaker, J. W. \& Chung, C. K. (forthcoming). Expressive writing and its links to mental and physical health. In H. Friedman (ed.), Oxford handbook of health psychology. New York: Oxford University Press.

Rudden, M. G., Milrod, B., Aronson, A. \& Target, M. (2008). Reflective functioning in panic disorder patients. Clinical observations and research design. In F. N. Busch (ed.) Mentalization. Theoretical considerations, research findings, and clinical implications. New York/London: Analytic Press.

Ryff, C. D. (1989). Happiness is everything, or is it? Explorations on the meaning of psychological well-being. Journal of Personality and Social Psychology 57: 1069-1081.

Scott, M. B. \& Lyman, S. M. (1968). Accounts. American Sociological Review 33(1): 46-62.

Staudinger, U. M., Smith, J. \& Baltes, P. B. (1994). Manual for the assessment of wisdom-related knowledge. Materialien aus der Bildungsforschung; 46, Berlin: Max-Planck-Institut für Bildungsforschung.

Streib, H. (1991). Hermeneutics of metaphor, symbol and narrative in faith development theory. $\mathrm{PhD}$ dissertation (Emory University). European University Studies, ser. 23, vol. 408. Frankfurt/M.: Lang.

- (1999). Sub-project 'Biographies in Christian fundamentalist milieus and organizations' (research project: "Drop-outs, converts and believers: contrasting biographical analyses of why individuals join, have a career and stay in, or leave religious/ideological contexts or groups," Part III). In Deutscher Bundestag.Referat Öffentlichkeitsarbeit (ed.), Final report of the Enquête Commission on 'So-called sects and psychogroups'. New Religious and ideological communities and psychogroups in the Federal Republic of Germany (pp. 402-414). Bonn: Deutscher Bundestag.

- (2000). Biographies in Christian fundamentalist milieus and organizations. Report to the Enquete Commission of the i3th German Parliament on 'So-called sects and psychogroups', translated by Ella Brehm. Bielefeld: University of Bielefeld, Evangelische Theologie.

- (2001). Faith development theory revisited: the religious styles perspective. International Journal for the Psychology of Religion 11: 143-158.

- (2003a). Religion as a Question of Style: Revising the Structural Differentiation of Religion from the Perspective of the Analysis of the Contemporary Pluralistic-Religious Situation. International Journal for Practical Theology 7(1): 1-22. 
- (2003b). Faith development research at twenty years. In R. R. Osmer \& F. Schweitzer (eds), Developing a public faith: new directions in practical theology. Essays in honor of James.W. Fowler (pp. 15-42). St. Louis: Chalice Press.

- (2005). Faith development research revisited: accounting for diversity in structure, content, and narrativity of faith. International Journal for the Psychology of Religion 15: 99-121.

- (2010). Conceptualizing and measuring religious development in terms of religious styles and schemata; new considerations. Paper for the Psychologie du développement religieux: questions classiques et perspectives contemporairnes, Lausanne 2010-V-27. On-line at: http:// pub.uni-bielefeld.de/pub?func $=$ drec\&id $=2276876$.

- (forthcoming). Conceptualisation et mesure du developpement religieux en termes de schemas et de styles religieux — resultats et nouvelles considerations. In P.-Y. Brandt \& J. M. Day (eds.), Psychologie du développement religieux: questions classiques et perspectives contemporaines. Geneva: Labor et Fides.

- (2012). Scoring sheet for faith development evaluation. Unpublished Manuscript.

Streib, H., Hood, R. W., Keller, B., Csöff, R.-M. \& Silver, C. (2009). Deconversion. Qualitative and quantitative results from cross-cultural research in Germany and the United States of America. Göttingen: Vandenhoeck \& Ruprecht.

Streib, H., Hood, R. W. \& Klein, C. (2010). The religious schema scale: construction and initial validation of a quantitative measure for religious styles. International Journal for the Psychology of Religion 20: 1-22.

Streib, H. \& Hood, R. W. (2011). 'Spirituality' as privatized experience-oriented religion: empirical and conceptual perspectives. Implicit Religion 14: 433-453.

Winnicott, D. W. (1971) Playing with reality. London: Tavistock.

Zinnbauer, B. J. \& Pargament, K. I. (2005). Religiousness and spirituality. In R. F. Paloutzian \& C. L. Park (eds), Handbook of the psychology of religion and spirituality (pp. 21-42). New York; London: Guilford Press. 